\title{
Seed set of male-sterile and male-fertile oilseed rape (Brassica napus) in relation to pollinator density
}

\author{
Ingolf STEFFAN-DEWENTER* \\ Agroecology, University of Göttingen, Waldweg 26, 37073 Göttingen, Germany
}

(Received 9 January 2002; revised 6 September 2002; accepted 25 September 2002)

\begin{abstract}
The effects of pollinator density on the seed set of a male-sterile (MS) and a male-fertile (MF) line of winter oilseed rape (Brassica napus) were studied in 24 isolation cages $\left(7.5 \mathrm{~m}^{2}\right.$ ). Pollinator treatments comprised of high pollinator density (a small honeybee colony and 10 mason bees, Osmia rufa), and a gradient of increasing $O$. rufa densities from zero (control) up to 100 bees per cage. High pollinator densities increased the seed weight per plant from $6.5 \mathrm{~g}$ to $56.9 \mathrm{~g}$ for the MS line. However seed weight did not differ between high pollinator densities and controls for the MF line. Increasing densities of $O$. rufa had a significant effect on almost all yield components of the MS line, but only marginal effects on the MF line. The number of seeds per pod, the seed weight per plant and the harvest index (seed weight/plant dry weight) of the MS line showed a significantly steeper increase with increasing bee density than that of the MF line. The results suggest that solitary bees could be used successfully to replace honeybees as pollinators of MS oilseed rape in isolation cages.
\end{abstract}

Brassica napus / Osmia rufa / Apis mellifera / pollination / plant breeding

\section{INTRODUCTION}

Winter oilseed rape (Brassica napus L. ssp. oleifera (Metzg.), Brassicaceae) is an important crop for the production of oilseed in temperate agricultural regions. In Germany in 1999 approximately 1.1 million hectares (12\% of the total agricultural area) were sown with oilseed rape (Statistisches Bundesamt, 2002). Oilseed rape is a predominantly self-pollinated crop with about one-third outcrossing (Becker et al., 1992). Pollen transport by insects, wind, or gravity as vectors is necessary (Williams, 1978; Eisikowitch, 1981; Free, 1993; Westcott and Nelson, 2001). Earlier studies have shown that the insect pollination of oilseed rape can lead to higher seed set and yield (Williams and Simpkins, 1989; Westcott and Nelson, 2001). However, these effects are dependent on cultivar, environmental growing conditions, and the compensatory capacity of the crop (Williams et al., 1987; Mesquida et al., 1988; Free, 1993; Westcott and Nelson, 2001). Further replicated experiments comparing yields with and without bees are still needed (Williams et al., 1987; Mesquida et al., 1988; Kevan and Phillips, 2001).

The significant heterosis for seed yield in oilseed rape has created interest in the development of hybrid cultivars (Riaz et al., 2001). Oilseed rape hybrids are based on male sterility mainly using the MSL system (Pinochet and Bertrand, 2000). Several oilseed rape hybrids have been recommended to farmers since 1994 (Pinochet and Bertrand, 2000). Hybrid composites consisting of a male-sterile component and a male-fertile component have been widely used in France and the United

\footnotetext{
* Correspondence and reprints

E-mail: isteffa@gwdg.de
} 
Kingdom. However, at several locations in Europe low seed set occurred, presumably due to pollen limitation (Pinochet and Bertrand, 2000). This could have been caused by low temperatures and rain reducing pollen transfer by wind and flight activity of insects. Additionally, the destruction of semi-natural habitats results in lower pollinator abundance in intensively managed agricultural landscapes thereby possibly causing pollinator limitation and reduced seed set (Steffan-Dewenter and Tscharntke, 1999; Steffan-Dewenter et al., 2001, 2002). More recently, restored hybrid cultivars producing normal amounts of pollen are grown, which successfully replace composite hybrids (Pinochet and Bertrand, 2000). In 2001, restored hybrids covered an area of about 670000 ha in Europe and 345000 ha in Germany (NPZ Hohenlieth, personal communication). However, for the breeding of restored hybrid cultivars and seed production for commercial growing, the combination of male-sterile (MS) and male-fertile (MF) lines is still necessary. In closed environments in particular, pollinators are required in order to achieve sufficient seed set. In addition to the honeybee, Apis mellifera L., which is often advocated as the only practical pollinator, the use of solitary bees and flies has been proposed (Torchio, 1990; Richards, 1993; Delaplane and Mayer, 2000). Yields of MS oilseed rape in isolation cages were increased by honeybee pollination (Mesquida and Renard, 1981) and varied with leafcutting bee stocking rates (Soroka et al., 2001). Pollination of other plant species in closed environments was improved successfully by using the solitary mason bee Osmia rufa Losinski and the syrphid fly Eristalis tenax (L.) (Jarlan et al., 1997; Schittenhelm et al., 1997). Because most studies compare control versus pollinator treatments, pollinator densities required for optimal seed set are as yet still unknown.

In this research, yield components of malesterile (MS) and conventional male-fertile (MF) oilseed rape cultivars were studied in relation to different pollinator treatments focusing on the following questions: (1) Is the seed set of MS and MF oilseed rape increased by bee pollinators?, (2) is the solitary mason bee Osmia rufa a suitable pollinator for caged MS oilseed rape?, and (3) which bee densities result in highest seed set?
Effects of pollinator density were studied using the solitary mason bee Osmia rufa (Linnaeus 1758) (Hymenoptera, Megachilidae). O. rufa is an above-ground nesting species that uses a variety of pre-existing cavities. It builds linear nests with several brood cells that are provisioned with pollen and nectar (Westrich, 1989). The species can be easily established in nesting traps made of wood or common reed (Tscharntke et al., 1998) and has been shown to perform well as a pollinator in closed environments, such as glasshouses (Free, 1993; Schittenhelm et al., 1997; Delaplane and Mayer, 2000).

\section{MATERIALS AND METHODS}

\subsection{Experimental design}

The research was carried out in 1999 at an experimental field station of the University of Göttingen ( $51^{\circ} 32^{\prime} \mathrm{N}$ and $\left.9^{\circ} 56^{\prime} \mathrm{E}\right)$, Germany, located in the Leine valley at an elevation of $150 \mathrm{~m}$, and with nutrient-rich loam soils.

Two closely related winter oilseed rape Brassica napus var oleifera (DC) Metzger lines, the MF pollen-producing line "Express" and the MS line "Express-MSL" (Norddeutsche Pflanzenzucht Hans Georg Lembke KG, 24363 Holtsee, Germany) were used for the experiments. The MS line "Express-MSL" has reduced stamens that produce no pollen and is therefore completely dependent on pollen transport from MF plants by insects or wind.

A total of 24 plots of $7.5 \mathrm{~m}^{2}(3 \times 2.5 \mathrm{~m})$ were established, each consisting of six rows of the two oil seed rape lines. In the centre of each plot a double row of the MF line "Express" was sown and on both sides a double row of the MS line "ExpressMSL". The row spacing within the double rows was $30 \mathrm{~cm}$ and between the double rows $50 \mathrm{~cm}$. The plant spacing within rows was $10 \mathrm{~cm}$. All plots were sown after regular soil cultivation at the end of August 1998. Standard fertiliser, herbicide and insecticide applications were made.

At the beginning of April 1999, before flowering started, all plots were caged with fine mesh plastic gauze with opening size $<1 \mathrm{~mm}$, (Baumann Saatzuchtbedarf, 74638 Waldenburg, Germany) using an iron frame of approximately $2 \mathrm{~m}$ height.

\subsection{Pollinator treatments}

O. rufa cocoons from a large, managed population on the field station of the Agroecology, 
University of Göttingen, were used. Cocoons were hibernated at $4{ }^{\circ} \mathrm{C}$ and separated into females and males according to the colour of their hair brush at the front of the head. About seven days before the expected beginning of rape flowering the storing temperature of the cocoons was increased to 20$25^{\circ} \mathrm{C}$. On emergence, the bees were distributed into 19 of the cages on 29 April 1999. At this date approximately 5 percent of the MF oil seed rape flowers had opened. The bee densities varied between 0 (three controls), 2 (two replicates), 5 (five replicates), 6, 8, 10, 15, 20, 25, 30, 40, and 50 female and the same number of male bees per cage.

In each cage we erected a post with two nesting traps for $O$. rufa, each consisting of about 150 internodes of common reed (Phragmites australis) in a plastic tube (diameter $10.5 \mathrm{~cm}$ ) (Tscharntke et al., 1998). The presence of males and nesting traps allowed mating, nest building and provisioning by the females. As a result, female flower-visiting activity and pollination effectiveness were expected to increase.

We established a second treatment to test whether a combination of high pollinator density and two pollinator species would result in a higher seed set than that achieved in our $O$. rufa density experiment. A small honeybee colony, five $O$. rufa females, and five males were put into each of five additional cages on the 29 April. Honeybee colonies were established using approximately $250 \mathrm{~g}$ of worker bees and a sealed queen cell in small polystyrene mating hives $(20 \times 30 \times 15 \mathrm{~cm}$, "Kirchhainer Begattungskästchen"; Wienold, 36341 Lauterbach, Germany). All pollinator treatments were distributed randomly to the cages.

\subsection{Yield components of oil seed rape}

On 9 July, five plants of each line were selected randomly and harvested from each cage before ripe pods split (a total of 240 plants). Each plant was put separately into a large paper bag and dried at 25$30{ }^{\circ} \mathrm{C}$ for about 4 weeks. The pods were then counted for each plant and all seeds were separated and cleaned from the pods by hand. The number of seeds per plant was measured using a seed counter (Contador E; Baumann Saatzuchtbedarf, 74638 Waldenburg, Germany). Seed weight per plant and plant dry weight including pod residues were measured. Additionally, the number of seeds per plant dry weight and the seed weight per plant dry weight were calculated in order to correct for differences in total plant size.

\subsection{Data analysis}

Mean values of five plants per cage were analysed for both the MS and the MF line. All data was tested for normality and, if necessary, transformed to achieve homogeneity of variances (Legendre and Legendre, 1998).

Simple linear regression analysis was used to test for the relationship between the density of pollinating bees and yield components. The response of MS and MF oilseed rape lines to different pollinator densities was analysed using a comparison of regression lines. F- and p-values are given for significant differences between slopes of two regression lines.

The differences between controls (no pollinators) and high density treatments (honeybees and mason bees) were compared separately for the MS and the MF line using one-way Anova. Additionally, yield components of the MS and the MF line were compared for the high pollinator density treatment. To determine significantly different means, the Scheffe-test for unequal numbers of replications was used (Sokal and Rohlf, 1995). Arithmetical means and standard errors are given in the figures and the text.

\section{RESULTS}

\subsection{Control versus high pollinator density}

Most yield components of the MS line responded positively to pollinator supplementation. The number of seeds per pod was approximately five times greater and number of seeds and seed weight per plant were about ten times higher in cages with high pollinator densities as compared to the controls (Tab. I). The number of pods per plant was only two times higher indicating that many developed pods contained no or only a few seeds in control cages. The plant dry weight was significantly higher in the control cages than in the pollinator treatment, presumably due to compensatory vegetative growth. The 1000 seeds weight was higher in the control cages than in those with high pollinator densities (Tab. I).

Effects of pollinator supplementation were less significant for the MF line. The number of seeds per plant, seed weight per plant and number of pods per plant were similar in both treatments (Tab. I). However, the number of seeds per pod was increased significantly from approximately 15 to 18 seeds per pod. The seed weight to plant dry weight ratio (i.e. the harvest index) was 0.5 in the control cages, as 
Table I. Mean yield components of a male-sterile and a male-fertile oilseed rape line: Comparison of controls (no pollinator, $\mathrm{n}=3$ cages) versus high pollinator densities (honeybee colony and 5 female and 5 male mason bees, $\mathrm{n}=5$ cages). The significant probability of one-way Anova is given.

\begin{tabular}{lcccccc} 
& \multicolumn{3}{c}{ Male-sterile line } & \multicolumn{3}{c}{ Male-fertile line } \\
\cline { 2 - 7 } \multicolumn{1}{c}{ Variable } & $\begin{array}{c}\text { Control } \\
\text { (no pollinator) }\end{array}$ & $\begin{array}{c}\text { High } \\
\text { pollinator } \\
\text { density }\end{array}$ & $\begin{array}{c}\boldsymbol{P} \text {-value } \\
\text { of difference }\end{array}$ & $\begin{array}{c}\text { Control(no } \\
\text { pollinator) }\end{array}$ & $\begin{array}{c}\text { High } \\
\text { pollinator } \\
\text { density }\end{array}$ & $\begin{array}{c}P \text {-value of } \\
\text { difference }\end{array}$ \\
\hline $\begin{array}{l}\text { Number of seeds per pod } \\
\text { Number of seeds per }\end{array}$ & $\mathbf{2 . 9}$ & $\mathbf{1 5 . 9}$ & $\mathbf{0 . 0 0 0 1}$ & 15.1 & 18.4 & 0.009 \\
plant & $\mathbf{1 0 1 8}$ & $\mathbf{1 0 7 4 0}$ & $<\mathbf{0 . 0 0 0 1}$ & 6709 & 7515 & 0.603 \\
Seed weight per plant (g) & $\mathbf{6 . 5}$ & $\mathbf{5 6 . 8}$ & $<\mathbf{0 . 0 0 0 1}$ & 29.5 & 29.1 & 0.95 \\
Number of pods per plant & $\mathbf{3 5 6 . 9}$ & $\mathbf{6 7 7 . 0}$ & $\mathbf{0 . 0 0 0 4}$ & 440.6 & 409.3 & 0.735 \\
Plant dry weight (g) & $\mathbf{1 2 5 . 4}$ & $\mathbf{9 3 . 1}$ & $\mathbf{0 . 0 0 5 9}$ & 57.0 & 49.1 & 0.432 \\
1000 seeds weight (g) & $\mathbf{6 . 4 9}$ & $\mathbf{5 . 3 4}$ & $\mathbf{0 . 0 3 3 6}$ & 4.43 & 3.87 & 0.0078 \\
$\begin{array}{l}\text { Number of seeds/ plant } \\
\text { dry weight (g) }\end{array}$ & $\mathbf{8 . 0 3}$ & $\mathbf{1 1 7 . 3}$ & $\mathbf{0 . 0 0 0 2}$ & 115.5 & 152.9 & 0.0091 \\
$\begin{array}{l}\text { Harvest index (seed } \\
\text { weight/ plant dry weight) }\end{array}$ & $\mathbf{0 . 0 5 2}$ & $\mathbf{0 . 6 2}$ & $<\mathbf{0 . 0 0 0 1}$ & 0.51 & 0.59 & 0.050 \\
\hline
\end{tabular}

compared to 0.6 in cages with high pollinator densities (Tab. I). The weight of single seeds was significantly higher for the controls whereas the plant dry weight did not differ between control and pollinator treatments (Tab. I).

In addition, the yield components of the two oilseed rape lines were compared. The number of seeds per plant $(\mathrm{F}=18.4$; df $=1,8$; $P=0.003)$ and the seed weight per plant (F $=100.8 ;$ df $=1,8 ; P<0.001)$ were significantly higher for MS plants as compared to MF plants in the high density pollinator treatment (Tab. I). The total plant dry weight of the MS line was significantly higher than that of the MF line in both the control treatment $(\mathrm{F}=26.3$; df $=1,4$; $P=0.007)$ and the pollinator treatment $(\mathrm{F}=65.2 ; \mathrm{df}=1,8 ; P<0.0001 ;$ Tab. I). The relative parameter of reproductive output, the seed weight to plant weight ratio, was similar for MS and MF plants in the high density pollinator treatment (Tab. I).

\subsection{Yield components in relation to $O$. rufa-densities}

In the second part of the experiment, the relationship between pollinator density and yield components was analysed for the two oilseed rape lines. The densities of $O$. rufa were significantly correlated with almost all yield components for the MS line, whereas the MF line only marginally responded to increasing pollinator densities (Tab. II). With increasing bee densities the number of seeds per pod increased significantly for the MS line from approximately 2 to 15 and did so with marginal significance for the MF line from about 12 to 20 seeds per pod (Fig. 1A; comparison of slopes: $\mathrm{F}=7.39$; $\mathrm{df}=3,34$; $P=0.010)$. The number of seeds per plant and seed weight per plant increased significantly for the MS line, but not for the MF line (Tab. II and Fig. 1B; comparison of slopes: $\mathrm{F}=6.74 ; \mathrm{df}=3,34 ; P=0.014)$. The number of pods did not correlate with pollinator densities. Plant dry weight and 1000 seeds weight were negatively correlated with pollinator densities for the MS but not for the MF line (Tab. II). The number of seeds per plant dry weight was positively correlated with pollinator densities for both lines (Tab. II). The seed weight to plant dry weight ratio (harvest index) was significantly correlated with pollinator density for the MS line, but not for the MF line (Fig. 1C; comparison of slopes: $\mathrm{F}=12.62$, $\mathrm{df}=3,34$; $P=0.001)$. In most cases the yield parameters of the MS line even at the highest $O$. rufa densities were lower than for the 


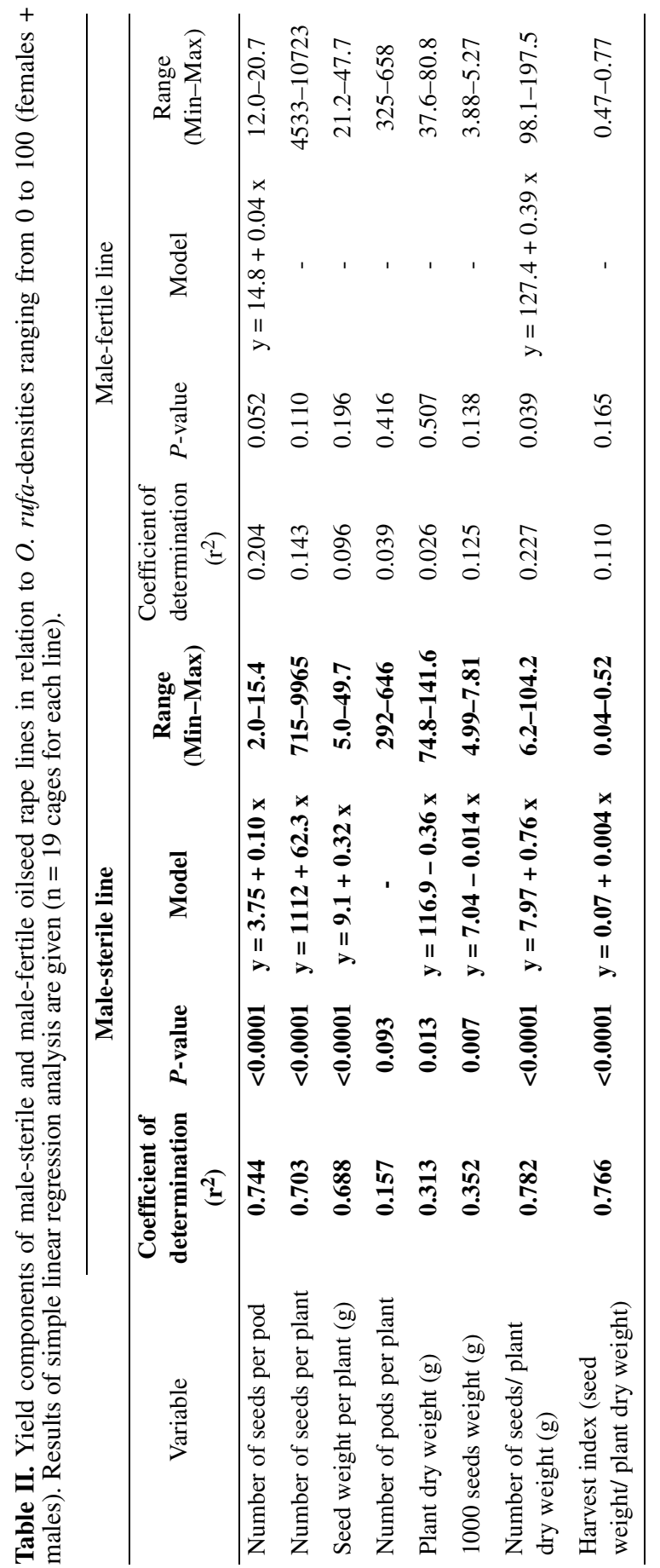



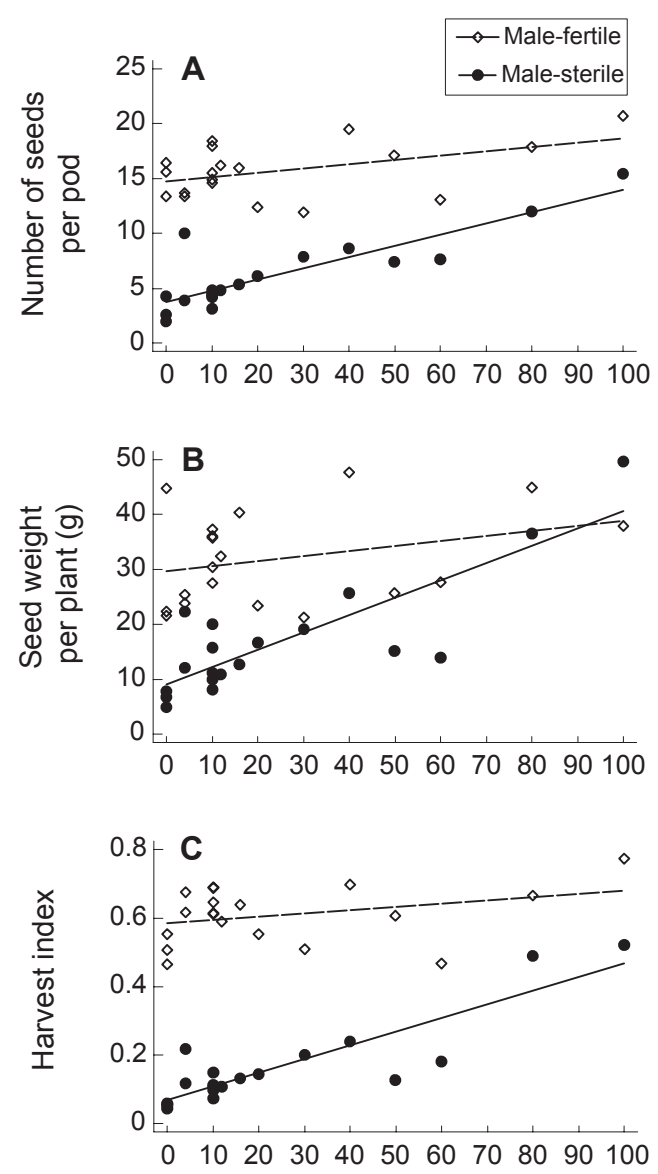

Number of bees per cage

Figure 1. Relationships between pollinator density of $O$. rufa (females and males) and yield components of a male-sterile (MS) and a malefertile (MF) oilseed rape line in 19 cages. Statistics for each regression are given in Table II. (A) Number of seeds per pod, (B) Seed weight per plant, and (C) Harvest index (seed weight per plant/ plant dry weight).

high pollinator density treatment with a combination of honeybees and mason bees (compare Tabs. I and II).

\section{DISCUSSION}

The main goal of this research was to analyse the relationship between pollinator density and yield components for two oilseed rape lines. The results provide evidence that yields of the MS line could be increased significantly by pollinators whereas the MF line did not show an increase in yield with addition of insects. To my knowledge, this is one of the few empirical studies showing the relationship between bee density and seed set in a closed environment.

The densities required to reach maximum seed set of the MS line were higher than expected. 50 female and 50 male $O$. rufa bees per cage $\left(13.4 \mathrm{bees} / \mathrm{m}^{2}\right)$ did not achieve the same seed weight per plant as in cages with a small honeybee colony in combination with five $O$. rufa females and five males. The linear increase of yield components with increasing bee densities in the regression models also suggest that pollinator saturation was not achieved in this experiment. The production of hybrid seed in isolation cages containing MS and MF rows of oilseed rape varied with leafcutting bee (Megachile rotundata Fabricius) stocking rates, with highest yield achieved at stocking rates equivalent to three charges at weekly intervals of 40 bees $/ \mathrm{m}^{2}$ (Soroka et al., 2001). Mesquida and Renard (1981) achieved approximate yields (measured as total seed weight per plot) for MS oilseed rape four times higher in cages with a high density of foraging honeybees as compared to cages without them. In contrast, an earlier study on germplasm regeneration of turnip rape (Brassica rapa) found acceptable seed set with only two $O$. rufa females per cage $\left(20 \mathrm{~m}^{2}\right)$, but other densities and maximum seed set were not evaluated (Schittenhelm et al., 1997). A related mason bee, Osmia cornuta, has been used for commercial pollination of orchard crops and only three females per almond tree were required to achieve maximum pollination (Bosch, 1994). Recommended densities of the leafcutting bee Megachile rotundata for lucerne fields have tended to increase over the years from 1.2-2.5 females $/ \mathrm{m}^{2}$ to 5.2 females/ $\mathrm{m}^{2}$ (Strickler, 1996; Delaplane and Mayer, 2000). Presumably, the high bee densities for MS oilseed rape were necessary, because pollination was limited by pollen transfer from only one third of MF plants to two third of MS plants in this androdioecious system.

It remains unresolved whether only the higher densities of honeybees or also the addition of a second pollinator species 
(O. rufa) improved seed set in the high density treatment. Recent results from field studies suggest that the combination of several complementary pollinator species differing in flower-visiting behaviour could be of more importance for high fruit set than only pollinator abundance (Hambäck, 2001; Klein et al., 2003). Future research should test this expectation by combining solitary bee species and/or syrphid flies. Such a "diversity strategy" could be more successful than just increasing the density of one pollinator species. The overcrowding in cages with social honeybees and bumble bees may in particular result in overexploitation of pollen and damage of flowers thereby possibly lowering fruit set (Mesquida et al., 1988).

In contrast to the MS line, only the number of seeds per pod and the number of seeds per plant dry weight of the MF line showed a marginally significant response to increasing pollinator densities. The seed weight per plant (the most important yield component) did not correlate with increasing $O$. rufa densities and it was not increased in the high pollinator density treatment (honeybee colony and 10 mason bees) as compared to control cages without introduced pollinators. However, the number of seeds per pod, the number of seeds per plant weight and the harvest index were significantly increased in cages with high pollinator densities indicating at least weak effects of insect pollination. Earlier studies have shown that insect pollination can positively affect several yield components of MF oilseed rape. However, these effects are dependent on cultivar and growing conditions and total yields are often not increased due to the considerable compensatory capacity of oilseed rape (Mesquida et al., 1988; Westcott and Nelson, 2001). Insect pollination leads to earlier cessation of flowering, and more synchronous pod and seed ripening, thereby possibly increasing the weight of seed harvest (Williams et al., 1987; Westcott and Nelson, 2001). Such pollinator effects could not be determined in this research because seed loss during harvest was minimised by early sampling and subsequent drying of the plants in paper bags.

The seed weight per plant was approximately twice as great for the MS than for the MF line in the high density pollinator treatment. This may be explained partly by the competitive advantage of the outer MS rows, but also confirms the high yield potential of hybrid cultivars (Pinochet and Bertrand, 2000). In the future, a further increase in the area sown with hybrid oilseed rape cultivars can be expected. This will increase the dependence of plant breeders on successful pollination of MS lines in cages or under field conditions for seed production.

The use of solitary bees for crop pollination demonstrates the economic value of non-Apis bees and the necessity to conserve a diverse native bee fauna (Torchio, 1990; Corbet, 1991; Kevan and Phillips, 2001). The results of this research show that the red mason bee $O$. rufa is a valuable alternative to honeybees for the pollination of MS oilseed rape in isolation cages for planned crossings.

\section{ACKNOWLEDGEMENTS}

I wish to thank I.H. Williams, B.E. Vaissière, C. Thies, H. Becker, A. Giercke, A. Braun and two anonymous referees for their helpful comments on the manuscript, the Institute of Plant Breeding (University of Göttingen) for sowing the experimental patches and building the isolation cages, and the "Forschungs- und Entwicklungsfond Raps (FER)" for financial support.

Résumé - Production grainière chez le colza (Brassica napus var. oleifera) mâle-stérile et mâle-fertile en relation avec la densité de pollinisateurs. Les effets de la densité de pollinisateurs sur les composantes du rendement du colza d'hiver (Brassica napus var. oleifera) ont été étudiés en 1999 sur une lignée mâle-stérile (MS) et une lignée mâle-fertile (MF). On a mis en place dans un champ expérimental près de Göttingen (Allemagne) 24 cages d'isolement $\left(7,5 \mathrm{~m}^{2}\right)$ comprenant chacune 2 rangs de MF et 4 rangs de MS. Les différents traitements comprenaient une densité élevée de pollinisateurs (une petite colonie d'abeilles domestiques ainsi que cinq osmies, Osmia rufa (Megachilidae), mâles et cinq osmies femelles et un gradient de densités croissantes d'osmies de 0 (témoin) à 100 par cage. Les densités élevées de pollinisateurs comparées aux cages témoins ont augmenté significativement le nombre de graines par cosse et le nombre de graines par poids sec de plante pour les deux lignées MS et MF (Tab. I). Néanmoins la composante la plus importante du rendement, le poids de graines par plante, a augmenté de $6,5 \mathrm{~g}$ à $56,9 \mathrm{~g}$ pour la lignée MS mais il n'y a pas eu de différence entre les deux traitements pour la lignée MF (Tab. I). Les densités élevées de pollinisateurs ont provoqué un 
doublement du poids de graines par plante pour la lignée MS par rapport à la lignée MF. Les densités croissantes d'osmies ont eu un effet significatif sur presque toutes les composantes du rendement pour la lignée MS mais n'ont eu que des effets marginaux pour la lignée MF (Tab. II). Le nombre de graines par cosse, le poids de graines par plante et l'indice de récolte (rapport poids de graines/poids de la plante) de la lignée MS ont augmenté significativement plus que pour la lignée MF quand la densité de pollinisateurs augmentait (Fig. 1A-C). Les densités nécessaires pour obtenir une production de graines suffisante ont été plus élevées qu'on ne s'y attendait. Une centaine d'osmies par cage $\left(13,4\right.$ abeilles $\left./ \mathrm{m}^{2}\right)$ ne fournissait pas le même poids de graines par plante qu'une petite colonie d'abeilles domestiques avec 10 osmies. Il semble qu'il faille une densité élevée de pollinisateurs pour le colza MS parce que seul un tiers des plantes fournit du pollen et que le transfert de pollen des plants MF aux plants MS est nécessaire à la pollinisation dans ce système androdioïque. Les résultats de cette recherche montrent que l'osmie rouge, Osmia rufa, constitue une alternative aux abeilles domestiques valable pour polliniser le colza MS en cages d'isolement lors de croisements planifiés.

\section{Brassica napus / Osmia rufa / Apis mellifera / pollinisation / sélection végétale}

\footnotetext{
Zusammenfassung - Fruchtansatz einer männlich-sterilen und einer männlichfertilen Winterrapssorte in Beziehung zur Bestäuberdichte. Der Einfluß der Bestäuberdichte auf Ertragskomponenten von Winterraps (Brassica napus var. oleifera) wurde für eine männlich-sterile (MS) und eine männlichfertile (MF) Sorte untersucht. Auf einer Versuchsfläche in der Nähe von Göttingen (Deutschland) wurden 24 Isolationskäfige $\left(7,5 \mathrm{~m}^{2}\right)$ aufgestellt, in denen sich jeweils 2 Reihen der MS Sorte und 4 Reihen der MF Sorte befanden. Die Bestäubervarianten umfaßten hohe Dichten (ein kleines Honigbienenvolk sowie 5 weibliche und 5 männliche Mauerbienen, Osmia rufa (Megachilidae)) und einen Gradienten zunehmender Bestäuberdichte von 0 (Kontrolle) bis zu 100 Bienen pro Käfig. Bei der MS Sorte und der MF Sorte führten hohe Bestäuberdichten im Vergleich zu den Kontrollen zu einer signifikant höheren Samenzahl pro Schote und Samenzahl pro Pflanzentrockengewicht (Tab. I). Die wichtigste Ertragskompontente, das Samengewicht pro Pflanze, nahm für die MS Sorte von 6,5 $\mathrm{g}$ auf $56,9 \mathrm{~g} \mathrm{zu}$, während für die MF Sorte keine Unterschiede zwischen der Kontrolle und der Bestäubervariante festgestellt werden konnten (Tab. I). Eine hohe Bestäuberdichte führte bei der MS Sorte zu einem doppelt so hohen Samengewicht pro Pflanze wie bei der MF Sorte.
}

Die Zunahme der Bestäuberdichte hatte einen signifikanten Einfluß auf fast alle Ertragskomponenten der MS Sorte, während für die MF Sorte nur marginale Veränderungen festgestellt wurden (Tab. II). Die Anzahl der Samen pro Schote, das Samengewicht pro Pflanze und der Ernteindex (Verhältnis Samengewicht zu Pflanzentrockengewicht) zeigten für die MS Sorte einen signifikant steileren Anstieg als für die MF Sorte (Abb. 1A-C). Die für einen hinreichenden Samenansatz benötigten Dichten waren höher als erwartet. Einhundert Mauerbienen pro Käfig $\left(13,4\right.$ Bienen $\left./ \mathrm{m}^{2}\right)$ erzielten im Vergleich zu der Variante mit einem kleinen Honigbienenvolk und 10 Mauerbienen ein geringeres Samengewicht pro Pflanze. Vermutlich wurde die hohe Bestäuberdichte für MS Winterraps benötigt, weil nur eine Drittel aller Pflanzen Pollen produzierte und der Pollentransfer von MF zu MS Pflanzen in diesem System für die Bestäubung notwendig ist. Die Ergebnisse zeigen, daß die Rote Mauerbiene (O. rufa) für die gezielte Kreuzung männlichsteriler Rapssorten in Isolationskäfigen eine wertvolle Alternative zur Honigbiene darstellt.

\section{Brassica napus / Osmia rufa / Apis mellifera / Bestäubung / Pflanzenzüchtung}

\section{REFERENCES}

Becker H.C., Damgaard C., Karlsson B. (1992) Environmental variation for outcrossing rate in rapeseed (Brassica napus), Theor. Appl. Genet. 84, 303-306.

Bosch J. (1994) The nesting behaviour of the mason bee Osmia cornuta (Latr) with special reference to its pollinating potential (Hymenoptera, Megachilidae), Apidologie 25, 84-93.

Corbet S.A., Williams I.H., Osborne J.L. (1991) Bees and the pollination of crops and wild flowers in the European community, Bee World 72, 47-59.

Delaplane K.S., Mayer D.F. (2000) Crop pollination by bees, CAB International, Wallingford, UK.

Eisikowitch D. (1981) Some aspects of pollination of oil-seed rape (Brassica napus L.), J. Agric. Sci. (Camb.) 96, 321-326.

Free J.B. (1993) Insect pollination of crops, Academic Press, London, UK.

Hambäck P.A. (2001) Direct and indirect effects of herbivory: Feeding by spittlebugs affects pollinator visitation rates and seedset of Rudbeckia hirta, Ecoscience 8, 45-50.

Jarlan A., De Oliveira D., Gingras J. (1997) Effects of Eristalis tenax (Diptera: Syrphidae) pollination on characterisitcs of greenhouse sweet pepper fruits, J. Econ. Entomol. 90, 1650-1654.

Kevan P.G., Phillips T.P. (2001) The economic impacts of pollinator declines: an approach to assessing the consequences, Conserv. Ecol. 5, 2. 
[online] URL: http://www.consecol.org/vol5/ iss 1/art8 (verified on 6 April 2003).

Klein A.-M., Steffan-Dewenter I., Tscharntke T. (2003) Fruit set of highland coffee increases with the diversity of pollinating bees, Proc. R. Soc. London B, in press.

Legendre P., Legendre L. (1998) Numerical Ecology, Elsevier, Amsterdam, The Netherlands.

Mesquida J., Renard M. (1981) Pollinisation du colza d'hiver mâle-fertile et mâle-stérile (Brassica napus L. var. oleifera Metzger) par l'abeille domestique (Apis m. mellifica L.). Effets sur la phénologie et le rendement, Apidologie 12, 345362 .

Mesquida J., Renard M., Pierre J.-S. (1988) Rapeseed (Brassica napus L.) productivity: the effect of honeybees (Apis mellifera L.) and different pollination conditions in cage and field tests, Apidologie 19, 51-72.

Pinochet X., Bertrand R. (2000) Oilseed rape grain yield productivity increases with hybrid varietal types: a first balance sheet with post registration tests in France and Europe, OCL-Oleagineux Corps Gras Lipides 7, 11-16.

Riaz A., Li G., Quresh Z., Swati M.S., Quiros C.F. (2001) Genetic diversity of oilseed Brassica napus inbred lines based on sequence-related amplified polymorphism and its relation to hybrid performance, Plant Breed. 120, 411-15.

Richards K.W. (1993) Non-Apis bees as crop pollinators, Rev. Suisse Zool. 100, 807-822.

Schittenhelm S., Gladis T., Rao V.R. (1997) Efficiency of various insects in germplasm regeneration of carrot, onion and turnip rape accessions, Plant Breed. 116, 369-375.

Sokal R.R., Rohlf F. (1995) Biometry, Freeman and Company, New York.

Soroka J.J., Goerzen D.W., Falk K.C., Bet K.E. (2001) Alfalfa leaf cutting bee (Hymenoptera: Megachilidae) pollination of oilseed rape (Brassica napus L.) under isolation tents for hybrid seed production, Can. J. Plant Sci. 81, 199-204.
Statistisches Bundesamt (2002) Datenreport 2002 Zahlen und Fakten über die Bundesrepublik Deutschland, Bundeszentrale für Politische Bildung, Bonn, Germany.

Steffan-Dewenter I., Tscharntke T. (1999) Effects of habitat isolation on pollinator communities and seed set, Oecologia 121, 432-40.

Steffan-Dewenter I., Münzenberg U., Tscharntke T. (2001) Pollination, seed set and seed predation on a landscape scale, Proc. R. Soc. London B 268, 1685-1690.

Steffan-Dewenter I., Münzenberg U., Bürger C., Thies C., Tscharntke T. (2002) Scale-dependent effects of landscape structure on three pollinator guilds, Ecology 83, 1421-1432.

Strickler K. (1996) Seed and bee yields as a function of forager populations: alfalfa pollination as a model system, J. Kans. Entomol. Soc. 69, 115201.

Torchio P.F. (1990) Diversification of pollination strategies for US crops, Environ. Entomol. 16, 1649-1656.

Tscharntke T., Gathmann A., Steffan-Dewenter I. (1998) Bioindication using trap-nesting bees and wasps and their natural enemies: community structure and interactions, J. Appl. Ecol. 35, 708719.

Westcott L., Nelson D. (2001) Canola pollination: an update, Bee World 82, 115-29.

Westrich P. (1989) Die Wildbienen BadenWürttembergs, Eugen Ulmer, Stuttgart, Germany.

Williams I.H. (1978) The pollination requirements of swede rape (Brassica napus L.) and of turnip rape (Brassica campestris L.), J. Agric. Sci. (Camb.) 91, 343-348.

Williams I.H., Martin A.P., White R.P. (1987) The effect of insect pollination on plant development and seed production in winter oil-seed rape (Brassica napus L.), J. Agric. Sci. (Camb.) 109, 135-139.

Williams I.H., Simpkins J. (1989) Honeybee pollination of the double low oil-seed rape line Ariana, Asp. Appl. Biol. 23, 343-346. 